\title{
Self-Examination of Patients with Malignant Melanoma in the Aftercare: Relevance of Psychosocial Factors and Instructions by the Physicians
}

\author{
Selbstuntersuchungen von Patienten mit malignem Melanom im Rahmen der \\ ambulanten Nachsorge: Bedeutung psychosozialer Faktoren und der ärztlichen \\ Anleitung zur Selbstuntersuchung
}
I. Zschocke ${ }^{a}$ J. Rhein ${ }^{b}$
H. Grimme
B. Stein ${ }^{a}$
F. A. Muthnyc
M. Augustin ${ }^{b}$

${ }^{a}$ Abteilung Psychotherapie und psychosomatische Medizin, Psychiatrische Universitätskliniken Freiburg, bUniversitäts-Hautklinik Freiburg, Institut für Medizinische Psychologie, Universität Münster

\section{Key Words}

Malignant melanoma $\cdot$ Skin cancer $\cdot$ Prevention · Self-examination · Coping

\begin{abstract}
Summary
Background: Several studies indicate that the prognosis of malignant melanoma (MM) can be improved if tumor progression, e.g. local recurrences and lymph node metastases, is detected at an early stage. Thus, instructed self-examination by the patients is recommended in aftercare. Although clinical experience shows that many patients do not sufficiently perform self-examination, no studies have so far focused on self-examination behavior. Objective: 1) To assess the self-examination behavior of patients with MM in aftercare, 2) to investigate factors that could explain the self-examination behavior. Methods: Cross-sectional study on 324 patients with MM in aftercare. Validated questionnaires evaluating the disease-related strain, coping with illness, and behavior and attitudes towards self-examination were handed to the patients. Results: $62 \%$ of the patients consider self-examination important. However, the operation site and pigmented lesions are inspected on a regular basis by only $29.6 \%$ of the patients, the lymph nodes are regularly self-examined by $9.9 \%$ of the patients. $73.2 \%$ of the patients claim that they have not been instructed by the physicians how to perform self-examinations. Patients who had been instructed in self-examinations rated the importance of self-examinations significantly higher. In this group, the frequency of self-examinations correlated with prognostic markers such as tumor depth and Clark level. By contrast, in the group of patients who had not been instructed, the frequency of self-examinations correlated with psychosocial strain. Conclusions: Although self-examinations in the aftercare are of considerable importance, most patients are not instructed and are not used to performing self-examinations. Patients who had been instructed show a more adequate and reasonable self-examination behavior.
\end{abstract}

\author{
Schlüsselwörter \\ Malignes Melanom · Hauttumor · Prävention \\ Selbstuntersuchung $\cdot$ Krankheitsverarbeitung
}

\section{Zusammenfassung}

Hintergrund: Verschiedene Studien deuten darauf hin, daß die Prognose des malignen Melanoms (MM) verbessert werden kann, wenn die Tumorprogression, d.h. lokales Wiederauftreten und Lymphknoten-Metastasen, in einem frühen Stadium entdeckt wird. Im Rahmen der Nachsorge wird deshalb eine angeleitete Selbstuntersuchung durch den Patienten empfohlen. Obwohl die klinische Erfahrung zeigt, daß viele Patienten diese Selbstuntersuchung nicht ausreichend durchführen, gibt es bisher noch keine Studien über das Selbstuntersuchungs-Verhalten von Patienten. Fragestellung: 1. Die Beurteilung des Selbstuntersuchungs-Verhaltens von Patienten mit MM im Rahmen der Nachsorge, 2. Ermittlung von Faktoren, die das Selbstuntersuchungs-Verhalten erklären. Methoden: Querschnittsstudie an 324 Patienten mit MM in der Nachsorge. Validierte Fragebogen zur Beurteilung der krankheitsbedingten Belastung, der Krankheitsverarbeitung und des Verhaltens bei und der Einstellung gegenüber der Selbstuntersuchung wurden den Patienten ausgeteilt. Ergebnisse: $62 \%$ der Patienten halten die Selbstuntersuchung für wichtig. Operationsnarbe und pigmentierte Hautstellen werden jedoch nur von $29,6 \%$ der Patienten regelmäßig untersucht, die Lymphknoten nur von 9,9\%. 73,2\% der Patienten geben an, sie seien nicht von den Ärzten angeleitet worden, Selbstuntersuchungen durchzuführen. Patienten, die nach eigenen Angaben Anleitung dazu erhalten haben, schätzten die Bedeutung der Selbstuntersuchungen signifikant höher ein. In dieser Gruppe korrelierte die Häufigkeit der Selbstuntersuchungen mit prognostischen Markern, wie Tumortiefe und Clark-Level. Im Gegensatz dazu korrelierte in der Patientengruppe ohne Anleitungen die Häufigkeit von Selbstuntersuchungen mit der psychischen Belastung. Schlußfolgerungen: Obwohl Selbstuntersuchungen in der Nachsorge von besonderer Bedeutung sind, geben die meisten Patienten an, nicht dazu angeleitet worden zu sein und sind in der Durchführung solcher Untersuchungen ungeübt. Personen mit Anleitung zeigen ein angemesseneres Verhalten bei der Selbstuntersuchung.

\begin{tabular}{ll}
\hline KARGER & ( 1999 S. K arger G mbH , Freiburg \\
Fax +49 761 4520714 & A ccessible online at: \\
$\begin{array}{l}\text { E-mail kargergmbh@aol.com } \\
\text { www.karger.com }\end{array}$ & http://B ioM edN et.com/karger
\end{tabular}

Dipl.-Psych. Ina Zschocke

A bteilung Psychotherapie und psychosomatische M edizin

Psychiatrische U niversitätskliniken Freiburg

H auptstraße 8, D-79104 Freiburg (G ermany)

Tel. +49-761-270-6796, Fax -6829

E-mail: zschocke@haut.ukl.uni-freiburg.de 


\section{Introduction}

Malignant melanoma ( $\mathrm{M}$ M) is a melanocytic tumor affecting mainly the skin. It is diagnosed in adults of all ages, most commonly between 50 and 60 years. The incidence of the tumor has been increasing steadily all over the world within the last 40 years (A ustralia: [22]; U SA : [1]; E urope: [4, 15]). The prognosis of $M M$ depends mainly on the tumor thickness and the histologic level. A ccordingly, early detection of $M M$ is a main issue in cancer treatment. Thus, M M screening has become part of public education and prevention campaigns all over the world [8, 23]. In order to increase the effectiveness and to reduce the costs of the screening programs, they have been partly supplemented by education campaigns teaching fullbody self-examination in the population [16, 23].

These preventive measures have been very effective with respect to reduction of the incidence of malignant skin tumors. Moreover, more tumors are now detected at an early stage $[10,14]$.

B eside early tumor detection, another focus of tumor prevention is the early recognition of tumor progression in melanoma aftercare. There is evidence that early detection and operation of local metastases prolongs survival time of MM patients [33]. The 10-year survival rate of $M M$ patients without metastases is about $75 \%$ [13]. It decreases to $20-40 \%$ in patients with loco-regional metastases and to $3 \%$ in patients with distant metastases [18]. Hence, the aftercare of M M patients focuses on the detection of tumor progression at an early stage. For this reason, in G ermany like in most Western countries, guidelines were developed to frame the aftercare of M M patients [25]. A ccording to these guidelines, M M aftercare is recommended for a period of 10 years after primary excision or any tumor progression. In G ermany, like in many countries, aftercare is intense during the first 5 years. E.g., in medium-risk M M , follow-ups are recommended every 3 months. Controls in the sixth to tenth year after diagnosis are carried out once a year.

The self-examination of the patients, including the site of the primary tumor, lymph nodes and pigmented lesions all over the body, is part of M M aftercare. The patients should be instructed by the dermatologist how to perform the self-examination. The fact that $40-50 \%$ of the patients discover lymphatic metastases on their own, underlines the importance of self-examination $[7,26,36]$ especially in the later period of MM aftercare, when the intervals are prolonged. Whereas these studies investigated the effects of aftercare and self-examination on the course of the tumor, no studies have so far focused on the factor that influence self-examination behavior. Clinical experience indicates that there are interindividual differences in the motivation and compliance of self-examination. Several factors may contribute to low self-examination, including sociodemographic variables such as gender, age and education as well as psychosocial factors.

$M$ any studies have revealed considerable disease-related psy- chosocial stress experienced by MM patients $[2,5,6]$; (overview: [29]). N umerous studies indicate that the individually experienced psychological strain due to cancer depends on the coping strategies a person has developed. Several different coping strategies have been described (O verview: [28]) and a distinction between favorable and non-favorable coping strategies in cancer has been undertaken (O verview: [19]). Several studies on coping with M M have been performed [1], $12,21,27,30,37]$. M ain results of the studies were

1) the detection of repressive coping as a major coping strategy in M M -patients [21, 27],

2) differences between the coping activity of $M M$ patients after primary excision and of patients in aftercare [37],

3) prognostically beneficial coping reactions found in $M M$ patients of stage I and II [12] and

4) positive effects of psychosocial interventions on the course of disease mediated by effective coping and emotional status [11].

Whereas the meaning of psychosocial stress and coping in patients with $\mathrm{MM}$ has been investigated in numerous studies, no studies so far have investigated the relationships between psychosocial factors on the one hand and preventive behavior and self-examination on the other hand.

Thus, the present study was designed to address the following questions:

1) How many of the MM-patients perform self-examinations?

2) Does the practice of self-examination correlate with sociodemographic, clinical or psychosocial parameters?

3) To which degree have melanoma patients in the aftercare been instructed to perform full-body self-examinations?

4) Does the instruction from the physicians to perform selfexaminations influence the patients' self-examination?

\section{Patients and Methods}

A cross-sectional study was conducted in melanoma aftercare of the Department of Dermatology, U niversity Hospital of Freiburg (G ermany) in order to explore the self-examination of M M patients. A Imost all of the M M patients in aftercare had been operated previously in the Dermatology Department and were thus familiar with the clinic. The initial patient information at the beginning of the melanoma aftercare was mostly transmitted by the treating dermatologists on ward. No special patient education programs were offered to the patients.

Patients in their second to tenth year of aftercare, e.g. 2 to 10 years after primary excision, were included in the study. 324 patients who were participants in a consecutive study that had been performed 2 years before were asked to participate in the study and informed about the survey by letter. In case of agreement to participate in the study, the patients were asked 
to complete a questionnaire and to undergo a medical examination in the $M M$ aftercare service. W ritten informed consent was obtained from the patients, who were given assurance of their anonymity. A s a matter of survey by letter and the fact that the study the patients had been participating in, had taken place two years in advance, 160 patients were excluded from the study, resulting in complete data for 164 patients.

The distribution of sociodemographic and clinical parameters of the sample is shown in table 1.

Participants and refusers showed significant differences with respect to tumor depth, in that participants had an average $M M$ infiltration of $1.32 \mathrm{~mm}$ versus $1.97 \mathrm{~mm}$ in the refusers. A II other variables were equally distributed.

The following questionnaires were given to the M M patients:

\section{H ornheide Q uestionnaire on M alignant Skin Tumors (H Q )} [35]

This inventory was developed specifically for patients with $\mathrm{MM}$ and other malignant skin tumors. It determines the degree of psychosocial strain and subsequently the need for intervention in skin tumor patients, employing the following 8 dimensions: physical well-being, emotional well-being, fear of tumor progression, tension/restlessness, social support, insecurity, support from physicians, occupational and financial problems. The scores achieved on each scale are added up to a total score, which indicates the need for psychosocial intervention. The degree of disease-related psychosocial strain is derived from the individual scores.

\section{The Freiburg Q uestionnaire on Coping with IIIness ( $F Q C I)$} [24]

The FQ CI was developed for the assessment of coping behavior. It was applied in a validated, shortened version (FQCILIS) in the present study, using 35 items to determine the following aspects of coping: depressive coping, active coping, distraction, search for religious meaning and minimization.

\section{Q uestions with Regard to Full-B ody Examination of the Patients}

Four questions were formulated specifically for the purpose of this study. The patients are asked if they had been instructed to perform a full-body self-examination to control tumor progression. Secondly, the patients should evaluate the relevance of self-examination during $M M$ aftercare. Finally, the patients are asked how often they have examined their body with respect to a) the site of the primary tumor, b) the lymph nodes and c) other pigmented lesions anywhere on the body surface.
Table 1. Clinical data of the participants of the study, $n=164$

\begin{tabular}{|c|c|}
\hline & $\%$ \\
\hline Sex, $f: m$ & $59.8: 40.2$ \\
\hline \multicolumn{2}{|l|}{ M elanoma type } \\
\hline Superficial spreading M M & 59.8 \\
\hline L entigo maligna M M & 6.1 \\
\hline Nodular M M & 16.5 \\
\hline A kro-lentiginous M M & 1.8 \\
\hline A melanotic M M & 2.4 \\
\hline Other & 8.5 \\
\hline U ncertain & 4.9 \\
\hline \multicolumn{2}{|l|}{ Tumor thickness } \\
\hline$<0.75 \mathrm{~mm}$ & 38.4 \\
\hline$<1.5 \mathrm{~mm}$ & 33.3 \\
\hline$>1.5 \mathrm{~mm}$ & 28.3 \\
\hline \multicolumn{2}{|l|}{ Clinical stage/Clark level } \\
\hline Stage I & 31.0 \\
\hline Stage II & 46.2 \\
\hline Stage III (regional/lymph node metastases) & 21.2 \\
\hline Stage IV distant metastases & 1.3 \\
\hline \multicolumn{2}{|l|}{ Time passed since tumor diagnosis } \\
\hline 2-4 years & 29.5 \\
\hline 4-7 years & 35.7 \\
\hline $7-10$ years & 34.8 \\
\hline
\end{tabular}

\section{Statistical A nalysis}

Statistical analysis was performed with SPSS 6.0 for Windows. The questionnaires ( $\mathrm{FQCl}, \mathrm{HQ})$ were analyzed using validated scales. Significances were calculated by t-Test for independent random samples on interval scale level. Correlations were calculated by the Pearson's coefficient. $D$ ata on a nominal and ordinal scale level were analyzed by means of the $\mathrm{Chi}$-square-test. D ifferences were defined to be significant on a $5 \%$ level for all computations.

\section{Results}

\section{Self-E xamination}

Taken together, $59.2 \%$ of the M M patients consider full-body self-examination to be important or very important (fig. 1). By constrast, about $16 \%$ regard the self-examination as neither important nor unimportant and $24.7 \%$ percent regard the self-examination as not important.

However, significantly more patients $(39.6 \%)$ regularly ('often' or 'very often') examine the operation site and pigmented lesions on their body. $31.3 \%$ quote to examine themselves from time to time. $23.2 \%$ claim to examine themselves rarely, and $6.1 \%$ of the patients state they never examine these areas. 
Fig. 1. Consideration of importance of the patients' self-examination $(n=164)$.
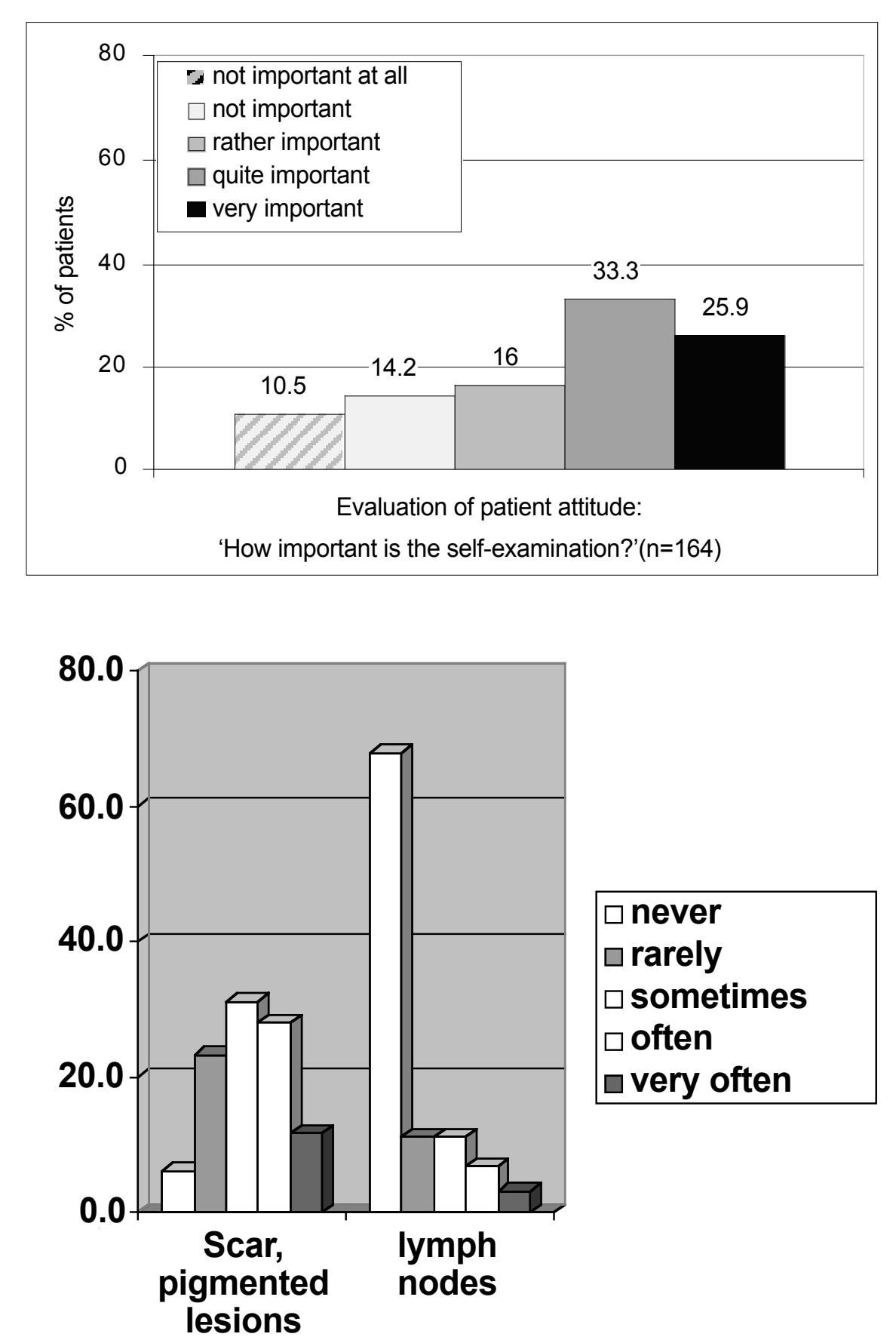

Fig. 2. Self-examination of melanoma patients in aftercare $(n=162)$.
Concerning self-examination of the regional lymph nodes, the majority of the patients ( $67.9 \%$ ) does not perform self-examinations at all (fig. 2). $11.1 \%$ say both, that they examine themselves rarely or from time to time. O nly $9.9 \%$ examine their lymph nodes often or very often.

The differences between patients performing self-examinations of either the operation site or the lymph nodes and patients who do not perform self-examinations were calculated statistically. The two groups did not differ in terms of any sociodemographic variables such as age, sex and education nor in terms of somatic variables such as tumor depth or Clark level and the time that had passed since the tumor diagnosis (data not shown).
Instruction of Full-B ody Self-E xamination

Firty-five out of 164 M M patients (26.8\%) report that they had been instructed by a physician in performing full-body self-examination within M M aftercare. 119 patients (73.2\%) claim to have not been instructed.

Statstical calculations revealed no differences between patients who had been instructed and those who had not been advised to perform self-examinations. The two patients groups did not differ from one another with respect to age, sex, and education nor any somatic variables such as tumor depth, Clark level or time since diagnosis (data not shown). 
Table 2. Effects of instructions by the physicians on the practice of self-examination

\begin{tabular}{llllll}
\hline & \multicolumn{2}{l}{ Instructed by the physician } & Test & Significance \\
\cline { 2 - 3 } & yes $(n=45)$ & no $(n=119)$ & & \\
\hline $\begin{array}{c}\text { Patients' estimation of full-body } \\
\text { self-examination (mean) }\end{array}$ & 2.57 & 2.25 & $2.38^{\mathrm{a}}$ & $*$ \\
$\begin{array}{c}\text { Frequency of self-examination of } \\
\text { primary tumor site and } \\
\text { pigmented lesions (mean) }\end{array}$ & 3.42 & 3.0 & $1.91^{\mathrm{a}}$ & $* *$ \\
$\begin{array}{c}\text { Frequency of self -examination } \\
\text { of lymph nodes, } \%^{3}\end{array}$ & 51.2 & 26.1 & $7.24^{\mathrm{b}}$ & $*$ \\
\hline
\end{tabular}

1 Likert scale: not important $=1$, very important $=3$.

2 Likert scale: not at all $=1$, very often $=5$.

3 Dichotomous scale: 1 = yes, $2=$ no.

a t-Test for independent variables.

${ }^{b}$ Chi test.

$* p<0.05, * * p<0.01$.
Patients who have been instructed consider self-examination significantly more relevant (table 2) and show significantly higher frequency of self-examination than patients not having been instructed.

\section{Correlation between Self-Examination and Psychosocial Parameters}

In order to assess clinical, sociodemographic and psychosocial parameters that correspond with self-examination behavior, the correlation analyses were performed separately for the patients who had been instructed and the non-instructed patients.

1) Instructed patients: In the group of instructed patients ( $n=$ 45), the frequency of self-examination of lymph nodes correlated strongly with tumor anxiety as well as with the tumor depth and the Clark level (table 3). The self-examination of pigmented lesions and the site of operation did not correlate with any clinical or other parameter such as age, education, coping or psychosocial strain.

II) Not-instructed patients: In the group of patients who reportedly had not been instructed by the physicians, the frequency of self-examination of either the lymph nodes, the sites of the primary tumor or pigmented lesions correlated significantly with psychosocial stress: Patients who performed self-examination more frequently are more negatively reminded of the tumor, show more tumor anxiety, are more disturbed and show greater social insecurity. M oreover, the frequency of self-examination of lymph nodes is correlated with a perceived lack of support by the physicians, occupational and financial problems as well as with the overall tumor-specific stress (global score of the Hornheide Questionnaire). Contrary to the instructed patients, no correlations could be found between self-examination and somatic parameters such as tumor depth and Clark level.
There was no correlation between the frequency of self-examination and any of the coping strategies in either patient group.

Table 3. Correlation between self-examination of lymph nodes and somatic, sociodemographic, and psychosocial parameters in the group of patients who (a) had been instructed $(n=49)$ and (b) had not been instructed $(n=119)$ on how to perform self-examination by their physicians

\begin{tabular}{lll}
\hline Variable & $\begin{array}{l}\text { Pearson's } \\
\text { coefficient/significance }\end{array}$ \\
\cline { 2 - 3 } & instructed & not instructed \\
\hline Somatic parameters & & \\
Tumor level & $0.31^{*}$ & 0.07 \\
Tumor depth & $0.45^{* *}$ & 0.17 \\
Time since diagnosis & 0.08 & -0.18
\end{tabular}

H ornheide Q uestionnaire (H Q) psychosocial strain in 8 dimensions

$\begin{array}{lll}\text { Physical well-being } & 0.00 & 0.12\end{array}$

$\begin{array}{lll}\text { E motional well-being } & 0.14 & 0.16\end{array}$

$\begin{array}{lll}\text { Tumor anxiety } & 0.51^{* * *} & 0.23^{* *}\end{array}$

$\begin{array}{lll}R \text { estlessness } & 0.24 & 0.06\end{array}$

$\begin{array}{lll}\text { L ack of social support } & 0.23 & 0.12\end{array}$

$\begin{array}{lll}\text { Insecurity } & 0.15 & 0.23^{*}\end{array}$

$\begin{array}{lll}\text { L ack of support from physicians } & -0.02 & 0.22^{*}\end{array}$

Occupational/financial problems $\quad-0.14 \quad 0.21^{*}$

$\begin{array}{lll}\text { H Q global score } & 0.19 & 0.20^{*}\end{array}$

Freiburg Q uestionnaire on Coping with IIIness ( $\mathrm{FQCl}$ )

$\begin{array}{lll}\text { Depressive coping } & 0.21 & 0.00\end{array}$

$\begin{array}{lll}\text { A ctive coping } & 0.11 & 0.10\end{array}$

$\begin{array}{lll}\text { Distraction } & 0.29 & 0.17\end{array}$

$\begin{array}{lll}\text { Religious meaning } & -0.07 & 0.07\end{array}$

$\begin{array}{lll}\text { Minimization } & 0.12 & 0.11\end{array}$

Q uestions concerning the self-examination

Self-examination is important $\quad 0.24 \quad 0.48^{* * *}$

When practicing self-examination, I feel

uncomfortably, reminded of the tumor $0.56^{* * *} \quad 0.32^{* * *}$

${ }^{*} p<0.05,{ }^{* *} p<0.01,{ }^{* * *} p<0.001$. 


\section{Discussion}

The early detection of tumor progression, especially lymph node metastases, influences the prognosis of the melanoma disease. Since the self-examination of patients with $M M$ has been shown to be of definite importance for the course of disease after the initial operation, the melanoma guidelines recommend the inclusion of self-examinations in aftercare $(\mathrm{Or}$ fanos 1994). For this, precise instructions by the dermatologist as well as good patient insight into the importance of self-examinations are crucial. In practice, however, many patients lack good compliance with respect to self-screening.

Thus, the present study was performed in order to assess the self-examination behavior of M M patients and to identify somatic as well as psychosocial factors that could predict compliance with the physician's instructions.

The results of the present study show that in routine aftercare at a university dermatology clinic, only a quarter of the M M patients obviously had been instructed to perform the recommended self-examinations. Since patients with a lack of memory and mental acuity were excluded from study, it seems unlikely that this result is biased by a lack of memory. A Iso, the coping strategies 'distraction' and 'denial' of the $\mathrm{FQCI}$ were not significantly increased in those patients who reported to have not been instructed (results not shown).

The results suggest that patient instructions on how to perform self-examinations should be better integrated into the schedule of M M aftercare. If the finding of only about $25 \%$ of patients having been instructed were biased by a lack of the patients' memory, this loss of memory would suggest that the instructions should be intensified in initial patient education sessions or repeated regularly during aftercare.

A ccording to the present data, patients who have been instructed in self-examinations practise these self-examinations significantly more often. M oreover, the frequency with which these patients perform self-examinations varies according to the somatic characteristics of the tumor, particularly according to the prognosis. This seems a more reasonable behavior than in the group of non-instructed patients, where the frequency of self-examination correlates with the psychological status rather than with the objective somatic parameters. In the latter group, patients with a good prognosis but high psychosocial strain tend to perform self-examinations which are unnecessary and which add to the patients' fears. On the other hand, patients with a bad prognosis but little psychosocial strain tend to not undertake self-examinations, though this would be beneficial.

Taken together, these findings indicate that instructions by the dermatologists lead to a more adequate patient behavior. They particularly underline the great importance of specific patient instructions for self-examination from the dermatologists.

B eside the practical benefit of self-examinations for the early detection of recurrences, they also contribute to a more active coping behavior and the acquisition of autonomy and self-responsiveness. From the psychotherapeutic point of view, these consequences cannot be overestimated.

\section{References}

1 A merican Cancer Society: Cancer Facts and Figures. 1996.

2 Augustin M, Zschocke I, Dieterle W, Schöpf E, Muthny FA : Bedarf und M otivation zu psychosozialen Interventionen bei Patienten mit malignen Hauttumoren. Z Hautkrankheiten 1997;72:333338.

3 B aider L, Perez T, K aplan D e-N our A : G ender and adjustment to chronic disease: A study of couples with chronic cancer. Gen Hosp Psychiatry 1989; 1:1-8.

4 Blum A, Ellwanger U, G arbe C: D as M aligne M elanom der $\mathrm{H}$ aut. A nalyse der $\mathrm{D}$ aten des $\mathrm{Z}$ entralregisters $M$ alignes M elanom der D eutschen D ermatologischen G esellschaft, 1983-1995. K rebsverband $B$ aden-W ürttemberg e.V, 1996.

5 B randberg Y, B olund C, Sigurdardottir V: A nxiety and depressive symptoms at different stages of malignant melanoma. Psycho-O ncology 1992;1:71-78.

6 Brandberg $Y, M$ ansson-B rahme $E$, R ingborg $U$, Sjöden PO : Psychological reactions in patients with malignant melanoma. Eur J Cancer 1995;31A : 157-162.

7 d'H oedt B, Stroebel W, Stutte H, R assner G : N achsorge des malignen Melanoms an der Tübinger H autklinik; in: Orfanos CE, Garbe C (eds): Das maligne Melanom der $\mathrm{H}$ aut. München, Zuckschwerdt, 1990, pp 304-311.
8 D avis NC, H erron JJ: Q ueensland melanoma project: organization and a plea for comparable surveys. M ed J A ust 1966;1:643-644.

9 D erogatis $L$, A beloff $M$, M elisaratos $N$ : Psychological coping mechanisms and survival time in metastatic breast cancer. JA M A 1979;242:1504-1508.

10 Elwood M, G allagher R: Skin cancer epidemiology study in the 1996. The Third Symposium on the E pidemiology of M elanoma and Non-melanotytic Skin Cancer. M elanoma R esearch 1997:7:74-77.

11. Fawzy FI, Fawzy NW, H yun CS, Elashoff R, G uthrie D, Fahey JL, M orton DL: M alignant melanoma. E ffects of an early structured psychiatric intervention, coping, and affective state on recurrence and survival 6 years later. A rch G en Psychiatry 1993;50:681-689.

12 Foltys MJ, K nopf B: U ntersuchungen zur psychologischen $\mathrm{K}$ rankheitsbewältigung bei Patienten mit malignem M elanom. Z H autkr 1991;67:239-241.

13 Garbe $C$, B üttner $P$ : D ie Prognose des primären malignen Melanoms; in: Orfanos CE, Garbe C (eds): D as maligne $\mathrm{M}$ elanom der $\mathrm{H}$ aut. $\mathrm{M}$ ünchen, Zuckschwerdt, 1990, pp 41-59.

14 Garbe $C, B$ üttner $P, E$ llwanger $U, B$ röcker $E B$, Jung $E G$, Orfanos CE, R assner $G$, Wolff $H$ : D as Zentralregister $M$ alignes $M$ elanom der $D$ eutschen Dermatologischen Gesellschaft in den Jahren 1983-1993. E pidemiologische Entwicklungen und aktuelle therapeutische Versorgung des malignen M elanoms. 1995.
$15 \mathrm{G}$ arbe $\mathrm{C}$ : Epidemiologie des malignen M elanoms in Deutschland; in M acher $E, B$ röcker $E B, K$ olde $\mathrm{G}$ (eds): Tumoren der $\mathrm{H}$ aut: Jahrbuch der D ermatologie 1994/95. Stuttgart, Biermann 1994, pp 113120

16 Girgis A, Campbell E M , R edman S, Sanson Fisher RW: Screening for melanoma: a community survey of prevalence and predictors. Med J Aust 1991; 154:338-343.

17 G reer S, M orris T, Pettingale: Psychological Response to B reast Cancer: $E$ ffect on O utcome. Lancet 1979:2:785-787.

$18 \mathrm{H}$ äffner AC, G arbe C, Burg G, B üttner P, O rfanos $C E, R$ assner $G$ : The prognosis of primary and metastasising melanoma. A $n$ evaluation of the TNM classification in 2495 patients. Br J Cancer 1992; 66:856-861.

19 H eim E : Coping - E rkenntnisstand der 90er Jahre. PPmP 1998;9/10:321-337.

20 H eim E : Coping und A daptivität: G ibt es geeignetes oder ungeeignetes Coping? Psychother Med Psychol 1988;38:8-18.

$21 \mathrm{~K}$ neier AW, Temoshok L: R epressive coping reactions in patients with malignant melanoma as compared to cardiovascular disease patients. J Psychosom R es 1984;28:145-155.

$22 \mathrm{M}$ arks $\mathrm{R}, \mathrm{H}$ ill $\mathrm{D}$ : The public health approach to melanoma control. Prevention and early detection. International U nion against Cancer (UICC), 1992. 
$23 \mathrm{M}$ arks R: Melanoma prevention: is it possible to change a population's behavior in the sun? Pigment Cell Res 1994; 7:104-106.

24 Muthny FA: Freiburger Fragebogen zur Krankheitsverarbeitung. Weinheim, B eltz, 1989.

25 Orfanos CE, Jung E G, R assner G, Wolff H H, G arbe $C$ : Stellungnahme und $E$ mpfehlungen der Komission malignes M elanom der D eutschen D ermatologischen Gesellschaft zur Diagnostik, Behandlung und Nachsorge des $\mathrm{M}$ alignen $\mathrm{M}$ elanoms der H aut - Stand 1993/4. H autarzt 1994;45:285-291.

26 Rassner G, d'H oedt B, Stroebel W, Schippert W: Melanomnachsorge: Integriertes $\mathrm{N}$ achsorgekonzept der Tübinger $\mathrm{H}$ autklinik sowie $\mathrm{E}$ rgebnisse einer $\mathrm{U}$ mfrage zur M elanomnachsorge an deutschen H autkliniken. H autarzt 1990;41(Suppl X):94-97.

27 Rogentine $G N$, van Kammen DP, Fox BH, Docherty JP, R osenblatt JE, B oyd SC, Bunney WE: Psychological factors in the prognosis of malignant melanoma: A prospective study. Psychosom Med 1979;41:647-655.
28 R üger U, B lomer A F, Förster W: Coping - Theoretische Konzepte, Forschungsansätze, Meßinstrumente zur K rankheitsbewältigung. G öttingen, Verlag für Medizinische Psychologie im Verlag Vandenhoeck, 1990.

29 Söllner W, Zschocke I, A ugustin M : M elanompatienten: Psychosoziale B elastung, K rankheitsverarbeitung und soziale Unterstützung. PPmP 1998; 9/10:338-348.

30 Söllner W, Z schocke I, Z ingg-Schir M, R umpold G, Fritsch $P$, Stein $B, A$ ugustin $M$ : Interactive patterns of social support and individual coping strategies in melanoma patients and their correlations with adjustment to illness. Psychosomatics 1999 (accepted for publication 10/98).

31 Sommer T, Sommer G: Fragebogen zur Sozialen U nterstützung - F-SOZU 22. Deutsche Gesellschaft für Verhaltenstherapie, M aterialien, 1989.

32 Spiegel D, Bloom J, Yalom I: Group Support For Patients with Metastatic Cancer. A rch Gen Psychiatry 1981;38:527-533.
33 Stroebel W, Schlagenhauff B, M eier F, B reuninger $H$, Carl M, Fierlbeck G, G arbe C, Z immermann C, $R$ assner $G$ : Nachsorge bei Melanompatienten; in G arbe C (ed): D ermatologische O nkologie. B erlin, Springer, 1997, pp 407-413.

34 Temoshok L, H eller BW, Sagbiel R, B lois M, Sweet $D, D$ iClemente $R$, $G$ old $M$ : The relationship of psychosocial factors to prognostic indicators in cutaneous malignant melanoms. J Psychosom R es 1985; 29:139-153.

35 Tilkorn M, M awick R, Sommerfeld S, Strittmatter $G$ : Lebensqualität von Patienten mit bösartigen Gesichts- und Hauttumoren. Entwicklung eines Fragebogens und erste Ergebnisse einer Studie. R ehabilitation 1990;29:134-139.

36 Weiss M, Loprinzhi ChL, Creagan ET, D alton RJ Novotny $P, O$ 'Fallon J R : U tility of follow-up tests for detecting recurrent disease in patients with malignant melanomas. JA M A 1995;274:1703-1705.

37 Zschocke I, A ugustin M, M uthny FA : K rankheitsverarbeitung bei Patienten mit malignem $M$ elanom in verschiedenen $\mathrm{K}$ rankheitsphasen. Psychomed 1996;8:83-88. 